6 Islam A. A new bone marrow biopsy needle with core securing device. J Clin Pathol 1982;35:359-64.

7 Ellman L. Bone marrow biopsy in the evaluation of lymphoma, carcinoma and granulomatous disorders. $\mathrm{Am} \mathrm{J} \mathrm{Med}$ 1976;60:1-6.

8 Burke JS. The value of the bone marrow biopsy in the diagnosis of hairy cell leukaemia. Am J Clin Pathol 1978;70:876-84.

9 Islam A, Catovsky D, Goldman JM, Galton DAG. Value of long core biopsy in detection of discrete bone marrow lesions. Lancet 1979;i:878.

10 Glauert AM, Glauert RH. Araldite as an embedding medium for electron microscopy. J Biophys Biochem Cytol 1958;4:191-4.

11 Luft $\mathrm{JH}$. Improvements in epoxy resin embedding methods. J Biophys Biochem Cytol 1961;9:409-14.

12 Anderson WA, Andre J. The extraction of some cell components with pronase and pepsin from thin sections of tissue embedded in Epon-Araldite mixture. J Microsc 1968;7:343-9.

13 Spurr AR. A low viscosity epoxy resin embedding medium for electron microscopy. J Ultrastruct Res 1969;26:31-43.

14 Heyderman E, Monaghan P. Immunoperoxidase reactions in resin embedded sections. Invest Cell Pathol 1979;2:119-22.

15 Giddings J, Griffin RL, Maciver AG. Demonstration of immunoproteins in Araldite embedded tissues. J Clin Pathol 1982;35:111-14.

16 Islam A. Bone marrow structure in human leukaemias: A histological study by plastic embedding techniques. London: University of London (Thesis). 1982.

17 Stein H, Gatter K, Asbahr H, Mason DY. Methods in laboratory investigation: use of freez-dried paraffin-embedded sections for immunohistologic staining with monoclonal antibodies. Lab Invest 1985;52:676-83.

Requests for reprints to: Dr A Islam, Department of Medical Oncology, Roswell Park Memorial Institute, 666 Elm Street, Buffalo, New York, 14263, USA.

\section{Modified latex agglutination test for anticytomegalovirus, suitable for pretransfusion screening}

\author{
J A J BARBARA, H MOULSDALE, S BROWN, P D GRIFFITHS, * \\ M J BERRY, * M CONTRERAS From the North London \\ Blood Transfusion Centre, Deansbrook Road, \\ Edgware, Middlesex, and the* Royal Free Hospital, \\ London
}

The increasing requirements of immunosuppressed patients for blood and blood components from donors uninfected with cytomegalovirus (CMV) led us to search for a sensitive, rapid, convenient and economical test for screening blood donations for antibodies against this virus.

Initially, we used a modification of a commercial haemagglutination (HA) assay (Cetus Corporation, Berkeley, California); this entailed 10 -fold dilution of the red cells provided in the kit and assessment of agglutination in a microplate inclined at $70^{\circ}$ after centrifugation at $387 \mathrm{~g}$ for one minute. ${ }^{1}$ Although this test proved suitable for the selection of plasma with high titre anti-CMV for the manufacture of specific immunoglobulin, its sensitivity and specificity was unacceptably variable for selecting CMV free donations. This became apparent when $23 \%$ (28 of 124) donations found negative for anti-CMV by modified HA were found to be positive for CMV antibodies by radioimmunoassay. We therefore decided to use a modified latex agglutination as our routine screening test (CMV Scan, Becton and Dickinson, Baltimore, Maryland). We tested this assay in parallel with the modified HA test (MHA) using a sensitive radioimmunoassay described by Berry et $a l^{2}$ as a standard for comparison.

Accepted for publication 15 July 1986

\section{Methods}

For the latex agglutination test $25 \mu \mathrm{l}$ of test serum was pipetted on to black reaction cards and $15 \mu$ l of latex coated with CMV antigen was added and mixed, according to the manufacturer's recommendations. Positive and negative control sera were also tested. The card was placed on a humidified rotator for eight minutes and then read. Samples positive for antiCMV showed clear agglutination, whereas negative ones remained cloudy. The test was made more economical by diluting two volumes of the antigen coated latex with one volume of the titration buffer provided with the kit. Furthermore, the volumes of reagents were reduced to $15 \mu \mathrm{l}$ of test serum and $5 \mu \mathrm{l}$ of diluted latex. Even with these reduced volumes, the reactions could be read easily.

\section{Results}

Before using the modified latex test for screening donor sera, we confirmed that the reduced volume modifications, with or without dilution of the latex, provided the same end point titres as the standard method when either sera or plasma with high titre or low titre anti-CMV were assessed. When 252 donor serum samples found to give negative CMV antibody results by modified haemagglutination screen tests were rescreened under routine testing conditions by the reduced volume latex agglutination test (method A), $58(23 \%)$ were found to be positive by the second test. These 58 samples were then retested by various methods (table 1). A small number scored differently on this repeat testing.

Table 2 gives detailed results for nine negative or "discrepant" sera at repeat testing. Furthermore, when 50 serum samples from donors found to be negative for anti-CMV by modified haemagglutination and by the two latex test modifications, were tested by monoclonal radioimmunoassay, 48 were clearly negative, and two samples showed only traces of antibody to CMV. The figure shows the 
Table 1 Details of 58 sera, negative for anti-CMV by modified $\mathrm{HA}$ (but positive by latex screen) and retested by four methods

\begin{tabular}{|c|c|c|c|c|}
\hline & \multicolumn{2}{|c|}{ Radioimmunoassay } & \multicolumn{2}{|c|}{ Modified latex agglutination } \\
\hline & $\begin{array}{l}\text { Polyclonal } \\
\text { antibody }\end{array}$ & $\begin{array}{l}\text { Monoclonal } \\
\text { antibody }\end{array}$ & Method A & Method B \\
\hline \multirow{2}{*}{$\begin{array}{l}\text { No of anti-CMV } \\
\text { positive (\%) } \\
\text { No of anti-CMV } \\
\text { negative (\%) }\end{array}$} & $54(93)$ & $53(91)$ & $55(95)$ & $53(91)$ \\
\hline & $4(7)$ & $5(9)$ & $3(5)$ & $5(9)$ \\
\hline
\end{tabular}

$\mathrm{A}=$ volumes reduced by two thirds; $\mathrm{B}=$ volumes reduced by two thirds and latex diluted by one third.

Table 2 Detailed results of nine serum samples giving discordant results by different techniques

\begin{tabular}{|c|c|c|c|c|}
\hline \multirow{3}{*}{$\begin{array}{l}\text { Sample } \\
\text { identification } \\
\text { No }\end{array}$} & \multicolumn{4}{|c|}{ Method used for retesting after original latex screen } \\
\hline & \multicolumn{2}{|c|}{ Radioimmunoassay } & \multicolumn{2}{|c|}{ Modified latex agglutination } \\
\hline & Polyclonal & $\begin{array}{l}\text { Monoclonal } \\
\text { (anti-Fc IgG) }\end{array}$ & $\begin{array}{l}\text { Titration } \\
\text { (method A) }\end{array}$ & $\begin{array}{l}\text { Screen } \\
\text { (method B) }\end{array}$ \\
\hline $\begin{array}{r}3 \\
23 \\
28 \\
29 \\
36 \\
44 \\
46 \\
50 \\
54\end{array}$ & $\begin{array}{l}+ \\
+ \\
+ \\
\text { Negative } \\
+ \\
\text { Negative } \\
\text { Negative } \\
\text { Negative } \\
+ \\
+\end{array}$ & $\begin{array}{l}+ \\
+ \\
+ \\
\text { Negative } \\
+ \\
\text { Negative } \\
\text { Negative } \\
\text { Negative } \\
\text { Negative } \\
+\end{array}$ & $\begin{array}{l}+(1 / 32) \\
+(1 / 32) \\
\text { Negative } \\
+(1 / 128) \\
\text { Negative } \\
+(1 / 8) \\
\text { Negative } \\
+(1 / 4) \\
+(1 / 4)\end{array}$ & $\begin{array}{l}\stackrel{+}{+} \\
\stackrel{\text { Negative }}{+} \\
\stackrel{+}{\text { Negative }} \\
\text { Negative } \\
\text { Negative } \\
\text { Negative } \\
+\end{array}$ \\
\hline
\end{tabular}

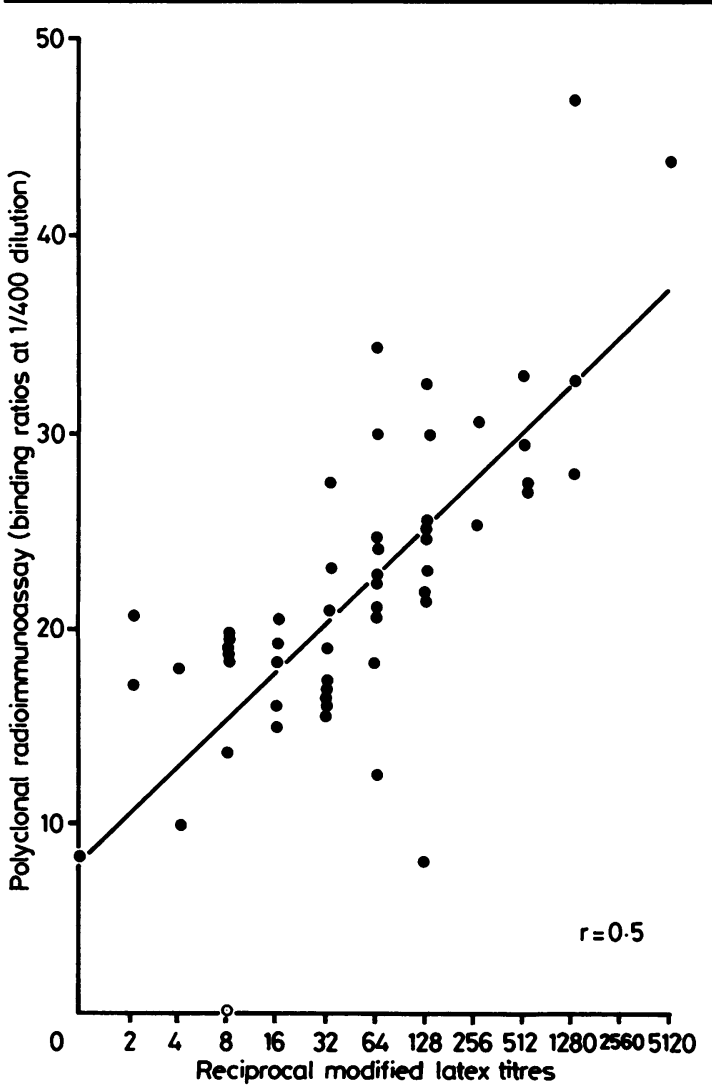

Correlation between modified latex $(\operatorname{method} A)$ and radioimmunoassay for anti-CMV assay. correlation between modified latex and radioimmunoassay for anti-CMV assay.

\section{Discussion}

The results indicate that the modified latex tests, as $\stackrel{\odot}{\varnothing}$ well as being rapid and relatively economical (15 to $\Rightarrow$ $20 \mathrm{p}$ per test), are both reasonably sensitive and $\frac{\mathrm{O}}{3}$ specific when compared with radioimmunoassay. At $\overrightarrow{ }$ the North London Blood Transfusion Centre we find it a very practical and convenient test for fulfilling nearly $90 \%$ of the 3500 annual requests that we? receive for platelet concentrates negative for $\mathrm{CMV}$ 윽 antibodies (de Silva etal, Proceedings of British. Blood Transfusion Service third annual meeting, $\delta$ Oxford, September 4-7 1985). In agreement with Taswell et al, ${ }^{3}$ the latex test has become the method of $\frac{}{7}$ choice at the Centre.

We acknowledge the generous gifts of reagents provided by Diamed Diagnostics and Becton and Dickinson.

\section{References}

1 Barbara JAJ. Microbiology in blood transfusion. Bristol: John ${ }_{C}$ Wright, 1983.

2 Berry NJ, Grundy JE, Griffiths PD. An improved radioimmunoassay method for the detection of IgG antibodies? against cytomegalovirus. $J$ Virol Methods 1986;13:343-500.

3 Taswell HF, Reisner RK, Rabe DE, Shelley CD, Smith TF. Comparison of three methods for detecting antibody to cytomegalovirus. Transfusion 1986;26:285-9.

Requests for reprints to: Dr J A J Barbara, North London $\bar{O}$ Blood Transfusion Centre, Deansbrook Road, Edgware, Middlesex, England. 